\title{
PENGARUH POSITIF PARIWISATA TERHADAP KEPUASAN HIDUP DAN NILAI CO CREATION PADA KOMUNITAS DI LINGKAR KEK MANDALIKA
}

\author{
Baiq Handayani Rinuastuti ${ }^{1}$, Akhmad Saufi ${ }^{2}$, Thatok Asmony ${ }^{3}$ \\ 1Program Studi Magister Manajemen Fakultas Ekonomi dan Bisnis Unram, \\ hrinuastuti@yahoo.com \\ 2,3Fakultas Ekonomi dan Bisnis, Universitas Mataram
}

\begin{abstract}
ARTICLE INFO
Keywords :

Positive tourism impacts, life satisfaction, cocreation value, Mandalika SEZ

Kata kunci:

Dampak posistif pariwisata, kepuasan hidup, co-creation value, KEK Mandalika

How to cite :

Handayani,RB., Saufi, Akhmad., Asmony, Thatok., (2019). PENGARUH POSITIF PARIWISATA TERHADAP KEPUASAN HIDUP DAN NILAI CO CREATION PADA KOMUNITAS DI LINGKAR KEK MANDALIKA. JMM UNRAM, 8(2),234243

DOI :

http://dx.doi.org/10.29303/jmm.v8i3.428
\end{abstract}

Dikumpulkan : 20 Mei 2019

Direvisi : : 14 Juni 2019

Dipublikasi : :09 Juli 2019

\begin{abstract}
Understanding community behavior related to the impact of tourism as well as the consequences of these impacts is an important matter to be studied in the effort to develop tourism in the future. The purpose of this study is to analyze the positive impact of tourism felt by residents in the Mandalika Special Economic Zone which can affect their life satisfaction and the willingness of the population to create co-creation values with tourists. The results showed that the positive effects of tourism activities and life satisfaction significantly affected the value of Co Creation, but the positive impact of tourism had a not significant effect on life satisfaction. The results of this study are expected to contribute to the development of theory, especially tourism marketing from the perspective of local residents. In addition, it can be used as a basis for consideration of policy makers in the development and marketing of tourism in the Mandalika Special Economic area.
\end{abstract}

Memahami perilaku penduduk terkait dampak pariwisata serta akibat dari dampak tersebut menjadi hal yang penting untuk dikaji dalam upaya pengembangan pariwisata di masa yang akan datang. Tujuan dari penelitian ini adalah untuk menganalisis dampak positif pariwisata yang dirasakan penduduk di Kawasan Ekonomi Khusus Mandalika yang dapat memengaruhi kepuasan hidup mereka serta kesediaan penduduk untuk menciptakan nilai bersama (co-creation value) dengan wisatawan. Hasil penelitian menunjukkan bahwa pengaruh positif dari kegiatan pariwista serta kepuasan hidup secara signifikan berpengaruh terhadap nilai Co Creation, namun dampak positif pariwisata berpengaruh tidak signifikan terhadap kepuasan hidup. Hasil penelitian ini diharapkan dapat berkontribusi pada perkembangan teori khususnya pemasaran pariwisata dari perspektif penduduk lokal. 
Selain itu dapat dijadikan dasar pertimbangan para pengambil kebijakan dalam pengembangan dan pemasaran pariwisata kawasan Ekonomi Khusus Mandalika

Copyright @ 2019 JMM UNRAM. All rights reserved.

\section{PENDAHULUAN}

Melibatkan warga dalam penciptaan nilai pariwisata tidak hanya diinginkan, tapi juga keharusan (Lin, 2017). Menurut Sharpley (2014) esensi pariwisata adalah interaksi antara wisatawan dan warga. Bimonte dan Punzo (2016) menekankan peran yang sama pentingnya dari kedua belah pihak. Namun, sebagian besar penelitian hanya berfokus pada penciptaan nilai antara wisatawan dan penyedia layanan pariwisata (Cabiddu, Lui, \& Piccoli, 2013; Sfandla \& Bjork, 2013), atau antara wisatawan dan wisatawan lainnya Rihova, Buhalis, Moital, \& Gouthro, 2015).

Pariwisata pada dasarnya adalah tentang orang-orang yang bepergian jauh dari rumah untuk berinteraksi dengan orang lain dan tempat lainnya (Sharpley, 2014). Hal Ini melibatkan pertemuan dua populasi: turis dan penduduk (Bimonte \& Punzo, 2016). Pengalaman pertemuan dan interaksi mereka dapat memengaruhi kepuasan, kesejahteraan dan perilaku masa depan mereka (Sharpley, 2014), karena kedua belah pihak memiliki kepentingan dan harapan, yang saling menguntungkan maupun konflik potensial antara kedua belah pihak (Bimonte \& Punzo,2011, 2016).

Semakin banyak literatur mengeksplorasi nilai co-creation di bidang pariwisata, namun pengetahuan tentang apa dan bagaimana penciptaannya masih terbatas (Rihova et al., 2015). Beberapa studi (Nunkoo \& Gursoy, 2012; Sinclair-Maragh \& Gursoy, 2016; Stylidis \& Terzidou, 2014) mengakui pentingnya penduduk destinasi dalam mendukung pengembangan pariwisata, terutama karena keberhasilan pariwisata bergantung pada keramahtamahan penduduk dan dukungan aktif mereka. Literatur menunjukkan bahwa perilaku penduduk yang mendukung pengembangan pariwisata sebagian besar dipengaruhi oleh sikap mereka terhadap dampak pariwisata (Lepp, 2007; Nunkoo \& Gursoy, 2012).

Dalam hubungan penduduk lokal dan wisatawan sikap positif penduduk terhadap pengembangan pariwisata ditunjukkan oleh penciptaan value yang dapat memberikan pengalaman dan kepuasan bagi wisatawan. Pentinganya penciptaan co creation dari penduduk diharapkan dapat memberikan pengalaman yang menyenangkan bagi wisatawan, meningkatkan kepuasan wisatawan. Hal ini menunjukkan pentingnya penelitian lebih lanjut terhadap perilaku penduduk lokal pada kesediaan mereka dalam memberikan sikap dan perilaku yang mendukung terhadap kegiatan pariwisata.

Kawasan Ekonomi Khusus (KEK) Mandalika ditetapkan melalui Peraturan Pemerintah Nomor 52 Tahun 2014 untuk menjadi KEK Pariwisata. KEK Mandalika diharapkan dapat mengakselerasi sektor pariwisata Provinsi Nusa Tenggara Barat yang sangat potensial. Memiliki konsep pengembangan pariwisata berwawasan lingkungan dengan pembangunan obyek-obyek wisata dan daya tarik wisata yang selalu berorientasi kepada kelestarian nilai dan kualitas lingkungan hidup yang ada di masyarakat, KEK Mandalika diharapkan dapat menjadi kawasan yang berkelanjutan meningkatkan kunjungan wisatawan.

Penelitian ini bertujuan untuk: (1) Membuktikan dan menganalisis signifikansi pengaruh dampak positif ekonomi, sosial, budaya, dan lingkungan pembangunan pariwisata terhadap penciptaan nilai co-creation dengan wisatawan, (2) Membuktikan dan 
menganalisis signifikansi pengaruh dampak positif ekonomi, sosial, budaya, dan lingkungan pembangunan pariwisata terhadap kepuasan hidup penduduk lokal, (3) Membuktikan dan menganalisis signifikansi pengaruh kepuasan hidup penduduk lokal terhadap penciptaan nilai-co creation dengan wisatawan.

\section{TINJAUAN LITERATUR}

\subsection{Nilai pembangunan pariwisata yang dirasakan dan nilai co creation}

Konsep nilai co-creation didasarkan pada asumsi bahwa pelanggan akan berperan aktif dalam kolaborasi dengan perusahaan untuk menciptakan nilai bersama melalui berbagai tahap rantai nilai dari produksi ke konsumsi (Prahalad \& Ramaswamy, 2004). Demikian pula dalam kegiatan pariwisata, wisatawan biasanya melakukan peran aktif mencari pengalaman yang berarti dan mudah diingat (Ritchie \& Hudson, 2009), oleh karena itu nilai pariwisata lebih tepat dianggap sebagai 'value-in-use' yang muncul saat wisatawan menggunakan, mengalami layanan pariwisata dalam konteks pengalaman mereka sendiri (Vargo \& Lusch, 2004).

Nilai co-creation biasanya dikonseptualisasikan sebagai proses pertukaran sumber daya, dan interaksi dari pelaku yang terlibat sehingga memungkinkan pertukaran sumber daya dan nilai yang dihasilkan secara timbal balik (Groco, 2008; Vargo \& Lusch, 2004). Dasar teoritis penciptaan nilai bersama dapat ditelusuri kembali ke teori pertukaran sumber daya sosial (Foa \& Foa, 1975 dalam Lin, 2017Grissemann dan Stokburger-Sauer (2012) berpendapat bahwa industri pariwisata ditandai oleh layanan kontak tinggi dan wisatawan memainkan peran utama dalam penciptaan layanan pariwisata. Pihak industri pariwisata seperti perhotelan, maupun penduduk lokal diwajibkan untuk menciptakan nilai co-creation (Bimonte \& Punzo, 2016; Gursoy, Jurowski, \& Uysal, 2002; Sharpley, 2014).

\subsection{Persepsi dampak pembangunan pariwisata dan penciptaan nilai co-creation}

Penelitian tentang pengembangan pariwisata menunjukkan bahwa nilai-nilai yang diciptakan dari pariwisata bagi penduduk sebagian besar adalah manfaat ekonomi dan sosial budaya bagi penduduk lokal, sedangkan biaya utamanya adalah dampak pariwisata terhadap lingkungan, (Andersson \& Lundberg, 2013). Kepuasan hidup penduduk barubaru ini telah diteliti dalam kaitannya dengan dampak pariwisata yang dirasakan dan dukungan untuk pengembangan pariwisata. Kim et al. (2013) berpendapat bahwa pengaruh pariwisata yang dirasakan warga berpengaruh terhadap kepuasan hidup, yang pada gilirannya mempengaruhi kepuasan hidup secara keseluruhan.

\subsection{Dampak positif Pembangunan Pariwisata}

Pariwisata memiliki dampak positif terhadap berbagai aspek kehidupan manusia, baik ekonomi, sosial budaya dan lingkungan (Kim et al, 2013). Pengembangan pariwisata dapat memfasilitasi kegiatan masuk dan aktivitas bisnis di masyarakat setempat, yang memberikan kesempatan kerja yang lebih baik, pendapatan lebih tinggi dan standar kehidupan yang lebih baik bagi penduduk. Tingkat dampak ekonomi dari pariwisata mungkin bergantung pada berbagai tahap pengembangan pariwisata (Kim et al., 2013).

Literatur pengembangan pariwisata menunjukkan bahwa manfaat ekonomi dirasakan secara positif terkait dengan sikap dan dukungan terhadap pengembangan pariwisata (Gursoy \& Rutherford, 2004). Kim et al. (2013) mengungkapkan bahwa dampak ekonomi pariwisata juga mempengaruhi kesejahteraan material penduduk, yang selanjutnya memberikan kontribusi terhadap kepuasan hidup. Pariwisata dapat membawa 
dampak positif kepada masyarakat setempat. Misalnya, peluang untuk meningkatkan infrastruktur, fasilitas rekreasi seperti taman, dan lain-lain, dan untuk memberi lebih banyak acara budaya seperti pentas seni budaya tradisional. Kim et al. (2013) menemukan bahwa dampak budaya positif dari pariwisata mempengaruhi kesejahteraan emosional, yang menyebabkan kepuasan hidup.

Berdasarkan bukti dan teori, dapat diajukan hipotesis bahwa: terhadap

H1a. Dampak positif pembangunan pariwisata berpengaruh positif signifikan penciptaan nilai co-creation dengan wisatawan

H1b. Dampak positif pembangunan pariwisata berpengaruh positif signifikan terhadap kepuasan hidup penduduk lokal

\subsection{Kepuasan hidup dan nilai co-creation: teori broaden-and-build}

Kepuasan hidup adalah keseluruhan rasa kesejahteraan tentang kehidupan seseorang, yang mengacu pada sejauh mana seseorang mengalami pengaruh positif dan stabil selama periode tertentu dalam kehidupan mereka (Lyubomirsky, 2001). Persepsi penduduk terhadap dampak pariwisata mempengaruhi rasa kesejahteraan mereka di berbagai wilayah kehidupan, yang pada gilirannya mempengaruhi kepuasan keseluruhan kehidupan mereka (Kim et al., 2013). Woo dkk. (2015) menunjukkan bahwa kepuasan hidup warga semakin mempengaruhi dukungan bagi pengembangan pariwisata. Penelitian Lin et al (2017) mengemukakan bahwa kepuasan warga seiring dengan persepsi dampak pariwisata mempengaruhi partisipasi masyarakat dalam penciptaan nilai bersama dengan wisatawan yang mengunjungi tempat atau komunitas mereka, dengan demikian diajukan hipotesis bahwa:

H2. Kepuasan hidup berhubungan positif terhadap penciptaan nilai co-creation dengan wisatawan.

Berdasarkan tinjauan teoritis dan hasil penelitian sebelumnya, maka dalam penelitian ini diajukan kerangka konseptual sebagai berikut:

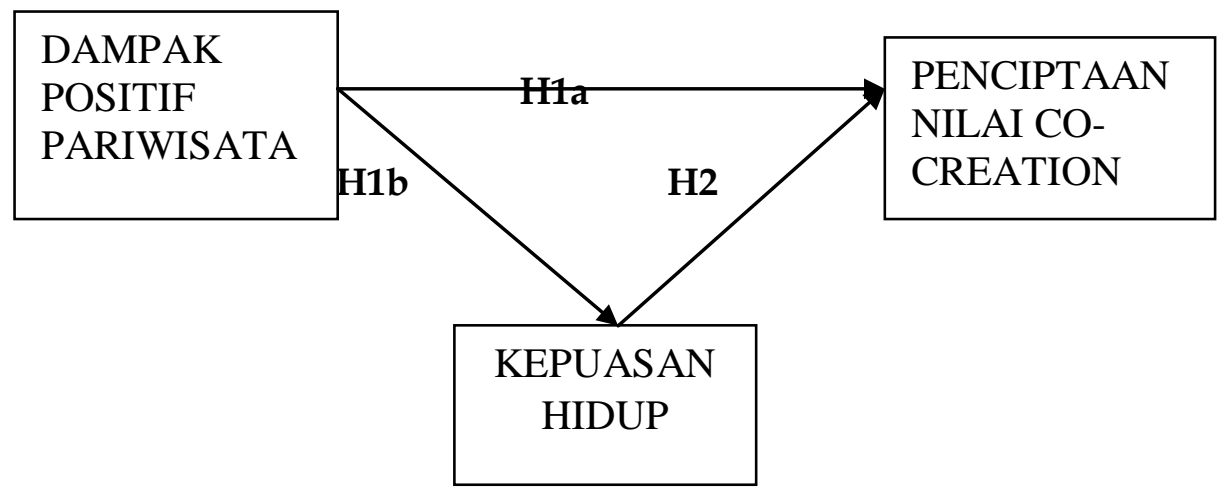

\section{METODOLOGI PENELITIAN}

Jenis penelitian yang digunakan adalah metode survey penjelasan (explanatory survey method), yang digunakan untuk menjelaskan hubungan antara variabel dampak positif pariwisata, kepuasan hidup penduduk dan penciptaan nilai bersama wisatawan. 
Penelitian ini dilakukan di Kawasan Ekonomi Khusus Mandalika Lombok. Populasi adalah seluruh penduduk dewasa yang bertempat tinggal di desa Kuta atau KEK Mandalika. Berdasarkan pertimbangan luasnya wilayah, banyaknya jumlah penduduk dewasa, dan keterbatasan waktu serta terkait alat analisis yang akan digunakan; maka jumlah sampel yang akan diambil sebanyak 100 orang penduduk dewasa, dengan teknik sampling; sampling aksidental. Metode Analisis Data dilakukan dengan Path analysis; yaitu suatu teknik untuk menganalisis hubungan sebab akibat yang tejadi pada regresi berganda jika variabel bebasnya mempengaruhi variabel tergantung tidak hanya secara langsung tetapi juga secara tidak langsung" (Robert D. Retherford 1993). Varibel dan item pengukuran variabel ditunjukan pada tabel berikut:

Tabel 1.1: Variabel Penelitian

\begin{tabular}{|c|c|c|}
\hline VARIABEL & ITEM & SUMBER \\
\hline $\begin{array}{l}\text { Dampak positif } \\
\text { Pariwisata; } \\
\text { merupakan persepsi } \\
\text { penduduk lokal } \\
\text { terhadap berbagai } \\
\text { manfaat ekonomi, } \\
\text { sosial budaya, dan } \\
\text { lingkungan yang } \\
\text { dirasakan akibat } \\
\text { pembangunan } \\
\text { (perkembangan) } \\
\text { pariwisata di KEK } \\
\text { Mandalika }\end{array}$ & $\begin{array}{l}\text { Pariwisata mendatangkan investasi bagi penduduk } \\
\text { Usaha lokal paling banyak mkendapat keuntungan } \\
\text { dari kegiatan pariwisata } \\
\text { Pariwisata menciptakan lapangan pekerjaan bagi } \\
\text { penduduk sekitar } \\
\text { Kehidupan masyarakat menjadi lebih baik akibat } \\
\text { berkembangnya pariwisata di Kuta/ Mandalika } \\
\text { Pariwisata mendorong produksi dan ketersediaan } \\
\text { makanan lokal } \\
\text { Pariwisata mendorong partisipasi dan kesenangan } \\
\text { penduduk untuk menyuguhkan pertunjukan lokal } \\
\text { seperti musik } \\
\text { Pariwisata meningkatkan kebanggan penduduk lokal } \\
\text { akan budayanya } \\
\text { Pariwisata membantu memperkenalkan warisan dan } \\
\text { industri budaya Kuta/ Mandalika } \\
\text { Pariwisata secara umum telah menambah keindahan } \\
\text { lingkungan } \\
\text { Pengembangan pariwisata melindungi lingkungan di } \\
\text { sekitar Kuta/ Mandalika) }\end{array}$ & $\begin{array}{l}\text { Woo, } \\
\text { Kim, } \\
\text { Uysal, } \\
2015 \\
\text { Lin, } 2017\end{array}$ \\
\hline $\begin{array}{l}\text { Life satisfaction; } \\
\text { perasaan kepuasan } \\
\text { hidup secara } \\
\text { keseluruhan, yang } \\
\text { dirasakan individu } \\
\text { sebagai hasil evaluasi } \\
\text { dari dampak } \\
\text { perkembangan } \\
\text { pariwisata di KEK }\end{array}$ & $\begin{array}{l}\text { Secara kesuluruhan, saya puas dengan hidup saya } \\
\text { Kondisi hidup saya sangat baik } \\
\text { Dalam banyak hal, hidup saya mendekati ideal } \\
\text { Sejauh ini saya mendapatkan hal-hal penting yang } \\
\text { saya inginkan dalam hidup } \\
\text { Jika saya dapat menjalani hidup lebih lama lagi, saya }\end{array}$ & $\begin{array}{l}\text { Woo et } \\
\text { al.,2015 }\end{array}$ \\
\hline
\end{tabular}




\begin{tabular}{|c|c|c|}
\hline Mandalika & $\begin{array}{l}\text { tidak ingin ada yang berubah } \\
\text { Secara umum, saya orang yang bahagia }\end{array}$ & \\
\hline $\begin{array}{l}\text { Nilai Co-Creation; } \\
\text { perilaku yang } \\
\text { menunjukan } \\
\text { kesediaan penduduk } \\
\text { lokal dalam } \\
\text { mendukung kegiatan } \\
\text { wisatawan guna } \\
\text { terciptanya nilai } \\
\text { pengalaman yang } \\
\text { bernilai bagi } \\
\text { wisatawan (value in } \\
\text { experience) }\end{array}$ & $\begin{array}{l}\text { Saya sangat menghargai wisatawan } \\
\text { Saya berupaya menyenangkan wisatawan dalam } \\
\text { berinteraksi } \\
\text { Saya bersedia menerima wisatawan sebagai tuan } \\
\text { rumah yang ramah } \\
\text { Saya bersedia memberikan informasi tentang berbagai } \\
\text { hal yang dibutuhkan wisatawan } \\
\text { Saya bersedia berbagi cerita tentang kebudayaan } \\
\text { lokal, cara hidup penduduk lokal, sejarah kepada } \\
\text { wisatawan }\end{array}$ & $\begin{array}{l}\text { Manuel, } \\
2017 ; \\
\text { Lin, } 2017\end{array}$ \\
\hline
\end{tabular}

Sumber: Dikembangkan dari berbagai penelitian sebelumnya

Sebelum item-item ini digunakan dalam kuesioner, dilakukan pengujian Validitas dan Reliabilitas. Berdasarkan hasil output SPSS menunjukkan bahwa corelation product moment pada seluruh item yang digunakan untuk mengukur seluruh variabel menunjukkan nilai $\mathrm{r}$ hitung lebih besar dari $\mathrm{r}$ tabel. Demikian pula cronbach alpha yang dihasilkan dari perhitungan lebih besar dari 0,7 (Nunnally,1994 dalam Ghozali, 2016). Dengan demikian seluruh item atau instrumen penelitian tersebut valid dan reliabel.

\section{HASIL DAN PEMBAHASAN}

Sebaran karakteristik dari responden dalam penelitian menunjukan bahwa responden laki-laki lebih dominan jika dibandingkan responden berjenis kelamin perempuan, sebagaian besar menjadi nelayan dan petani penggarap, 60 persen dari responden merupakan penduduk asli yang menetap semenjak mereka dilahirkan di tempat tersebut. Responden didominasi pada tingkat pendapatan dibawah Rp 3.000.000 rupiah per bulan.

\section{Analisis Statistik}

Guna membuktikan hipotesis yang diajukan, dilakukan pengolahan data dengan analisis jalur menggunakan program SPSS 21. Berdasarkan output SPSS diperoleh hasil sebagai berikut

Tabel 1. Model Summary, Coefficients

\begin{tabular}{|l|r|r|r|c|}
\hline \multicolumn{1}{|c|}{ Pengaruh } & \multicolumn{1}{|c|}{$\begin{array}{c}\text { Standardized } \\
\text { Coefficients }\end{array}$} & $\mathrm{t}$ & Sig. & Keterangan \\
\hline $\begin{array}{l}\text { Dampak Positif }(\mathrm{X}) \longrightarrow \text { Kepuasan } \\
\text { hidup (Y1) }\end{array}$ &,- 088 &,- 870 &, 387 & $\begin{array}{c}\text { Tidak } \\
\text { terdukung }\end{array}$ \\
\hline $\begin{array}{l}\text { Dampak Positif }(\mathrm{X}) \longrightarrow \text { Nilai Co - } \\
\text { Creation (Y2) }\end{array}$ & 0,915 & 22,752 &, 000 & Terdukung \\
\hline $\begin{array}{l}\text { Kepuasan hidup (Y1) } \longrightarrow \text { Nilai Co } \\
- \text { Creation (Y2) }\end{array}$ & 0,093 & 2,312 &, 023 & Terdukung \\
\hline Model 1; X terhadap Y1 & \multicolumn{3}{|l}{} & $\mathrm{R}^{2=}, 018$ \\
\hline
\end{tabular}


Berdasarkan pengujian hipotesis yang telah dilakukan maka dapat digambarkan hubungan variabel yang terbukti berpengaruh signifikan dalam penelitian ini, yaitu sebagai berikut:

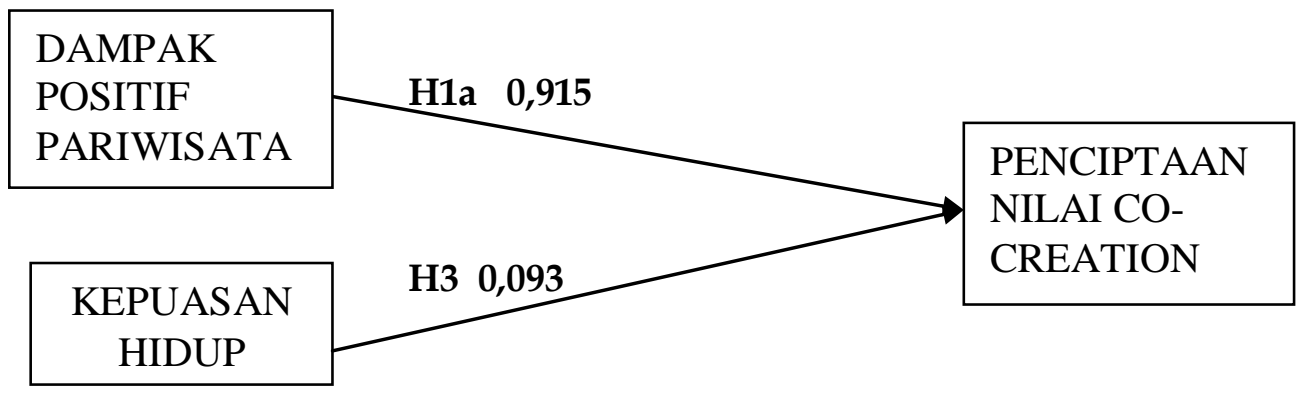

\section{PEMBAHASAN}

Hasil penelitian ini membuktikan bahwa pengaruh positif yang dirasakan penduduk secaraq langsung berpengaruh pada penciptaan nilai co creation dengan wisatawan. Berkembangnya pariwisata di suatu bdaerah dapat mendatangkan investasi bagi penduduk setempat, memberikan mereka lapangan pekerjaan, mengembangkan usaha yang mereka sudah kembangkan, dan pada akhirnya kehidupan masyarakat menjadi lebih baik. Selain itu semakin banyaknya kunjungan wisatawan menyebabkan masyarakat terdorong untuk berupaya sedemikian rupa memproduksi dan menjaga ketersediaan makanan lokal, seperti kelapa muda, ikan dan hasil launya yang dapat ditawarkan pada restoran atau hotel disekitar lokasi. Dari sisi seni budaya, perkembangan pariwisata mendorong partisipasi dan kesenangan penduduk untuk menyuguhkan pertunjukan lokal seperti musik, meningkatkan kebanggan penduduk lokal akan budayanya, serta mempromosikandan memperkenalkan keaslian budaya lokal. Pariwisata secara umum telah menambah keindahan lingkungan. Pembangunan berbagai sarana akomodasi dan fasilitas lainnya, sarana transportasi, jalan yang tertata dan terencana lebih baik memberikan suasana yang berbeda. Berbagai kondisi ini secara langsung maupun tidak langsung berdampak pada penduduk sekitar. Penduduk yang tinggal dan hidup sehari-harinya di sekitar Kuta Mandalika dapat merasakan perubahan tersebut. Karenanya perubahan yang baik tersebut dapat mempengaruhi sikap mereka yang pada akhirnya mempengaruhi keinginan mereka untuk dapat melakukan hal yang positif kepada wisatawan yang berkunjung. Gursoy dan Rutherford (2004) menunjukkan bahwa manfaat sosial dan budaya positif membawa dukungan bagi pariwisata.

Dalam kegiatan pariwisata, wisatawan biasanya melakukan peran aktif mencari pengalaman yang berarti dan mudah diingat (Ritchie \& Hudson, 2009), oleh karena Nilai co-creation dapat tercipta dengan asumsi bahwa orang memenuhi kebutuhan mereka melalui pertukaran sumber daya, dan cara orang memperoleh sumber daya yang dibutuhkan mereka dari orang lain adalah melalui interaksi sosial antara pihak-pihak pertukaran (Foa \& Foa, 1975 dalam Lin, 2017). Pelaku yang terlibat dalam pariwisata meliputi wisatawan, penyedia layanan pariwisata, penduduk dan pemangku kepentingan lainnya. Pihak industri pariwisata seperti perhotelan, maupun penduduk lokal diwajibkan untuk menciptakan nilai co-creation (Bimonte \& Punzo, 2016; Gursoy, Jurowski, \& Uysal, 2002; Sharpley, 2014). 
Hasil penelitian ini pula mendukung, adanya pengaruh signifikan kepuasan hidup terhadap terciptanya co-creation penduduk dalam berinteraksi dengan wisatawan. Kepuasan hidup adalah keseluruhan rasa kesejahteraan tentang kehidupan seseorang, yang mengacu pada sejauh mana seseorang mengalami pengaruh positif dan stabil selama periode tertentu dalam kehidupan mereka (Lyubomirsky, 2001). Woo dkk. (2015) menunjukkan bahwa kepuasan hidup warga semakin mempengaruhi dukungan bagi pengembangan pariwisata. Penelitian Lin et al (2017) mengemukakan bahwa kepuasan warga seiring dengan persepsi dampak pariwisata mempengaruhi partisipasi masyarakat dalam penciptaan nilai bersama dengan wisatawan yang mengunjungi tempat atau komunitas mereka.

Teori broaden-and-build menunjukkan bahwa pengalaman positif mempengaruhi memperluas lingkup pemikiran dan tindakan, dan membangun sumber daya pribadi (Fredrickson, 2001). Dengan kata lain, emosi positif memperluas fokus perhatian kognitif, meningkatkan kemungkinan cara berpikir alternatif, yang mengarah pada beragam tindakan yang lebih besar, dan akibatnya memfasilitasi pengembangan sumber daya pribadi seperti pengetahuan, keterampilan, kesehatan, dan jaringan sosial (Lyubomirsky, King, \& Diener, 2005). Penelitian sebelumnya telah menunjukkan bahwa emosi positif memicu berbagai perilaku kerja positif, seperti kreativitas, usaha dan kinerja yang lebih baik, serta perilaku pro-sosial, pro-lingkungan atau altruistik (Bissing-Olson, Iyer, Fielding, \& Zacher, 2013).

Kepuasan hidup adalah keseluruhan rasa kesejahteraan tentang kehidupan seseorang, yang mengacu pada sejauh mana seseorang mengalami pengaruh positif dan stabil selama periode tertentu dalam kehidupan mereka (Lyubomirsky, 2001). Persepsi penduduk terhadap dampak pariwisata mempengaruhi rasa kesejahteraan mereka di berbagai wilayah kehidupan, yang pada gilirannya mempengaruhi kepuasan keseluruhan kehidupan mereka (Kim et al., 2013). Woo dkk. (2015) menunjukkan bahwa kepuasan hidup warga semakin mempengaruhi dukungan bagi pengembangan pariwisata. Penelitian Lin et al (2017) mengemukakan bahwa kepuasan warga seiring dengan persepsi dampak pariwisata mempengaruhi partisipasi masyarakat dalam penciptaan nilai bersama dengan wisatawan yang mengunjungi tempat atau komunitas mereka.

\section{KESIMPULAN}

Hasil penelitian menunjukkan bahwa pengaruh positif dari kegiatan pariwista serta kepuasan hidup secara signifikan berpengaruh terhadap nilai Co Creation, namun dampak positif pariwisata berpengaruh tidak signifikan terhadap kepuasan hidup. Artinya bahwa semakin besar pengaruh postif pariwisatadan kepuasan hidup yang dirasakan penduduk maka akan semakin meningkatkan keinginan mereka untuk menciptakan co-creation. Dari koefisien pengaruh tiap variabel menunjukkan bahwa dampak positif pariwisata lebih berpengaruh terhadap penciptaan Nilai co-creation.

Berdasarkan hasil tersebut diharapkan para stake holder, terutama pemerintah sebagai regulator dan pengambil kebijakan dalam pengembangan pembangunan pariwisata, sedemikian rupa harus mempertimbangkan efek pembangunan tersebut terhadap penduduk obyek wisata. Masyarakat sedapat mungkin bisa merasakan dampak positif pariwisata, baik melaui penciptaan lapangan kerja, melibatkan penduduk dalam usaha-usaha pariwisata di lokasi, memberikan porsi bagi penduduk lokal untuk membuka usaha. Selain dampak ekonomi, para stake holder diharapkan mempertimbangkan adat 
istiadat budaya lokal baik dalam promosi maupun pembinaannya.Dengan demikian diharapkan dapat tercipta suatu kondisi yang kondusif yang dapat menciptakan nilai cocreation antara penduduk dengan wisatawan yang berkunjungguna terciptakan pariwisata yang berkelanjutan.

\section{DAFTAR PUSTAKA}

Andersson, T. D., \& Lundberg, E. (2013). Commensurability and sustainability: Triple impact assessments of a tourism event. Tourism Management, 37, 99e109.

Bimonte, S., \& Punzo, L. F. (2016). Tourist development and hosteguest interaction: An economic exchange theory. Annals of Tourism Research, 58, 128e139.

Cabiddu, F., Lui, T.-W., \& Piccoli, G. (2013). Managing value co-creation in the tourism industry. Annals of Tourism Research, 42, 86e107.

Chen, C. F., \& Chen, F. S. (2010). Experience quality, perceived value, satisfaction and behavioral intentions for heritage tourists. Tourism Management, 31(1), 29-35.

Fredrickson, B. L. (2001). The role of positive emotions in positive psychology: The broaden-andbuild theory of positive emotions. American psychologist, 56(3),218.

Ghozali, Imam. 2016. Aplikasi Analisis multivariate Dengan program IBM SPSS (Edisi 8), Cetakan ke VIII. Badan Penerbit Universitas Diponegoro. Semarang

Gursoy, D., Jurowski, C., \& Uysal, M. (2002). Resident attitudes: A structural modeling approach. Annals of Tourism Research, 29(1), 79e105.

Hair, J.F. 2010. Multivariate Data Analysis, 7th edition. Pearson Prentice Hall

Kim, K., Uysal, M., \& Sirgy, M. J. (2013). How does tourism in a community impact the quality of life of community residents? Tourism Management, 36, 527e540.

Lee, T. H. (2013). Ifluence a nalysis of community resident support for susta inable tourism development. Tourism Management, 34, 37e46.

Lepp, Andrew, (20017) Residents' attitudes towards tourism in Bigodi village, Uganda, Tourism Management, 28, 876-885

Liang, Z.-X., \& Hui, T.-K. (2016). Residents' quality of life and attitudes toward tourism development in China. Tourism Management, 57, 56e67.

Lin, Chen, \& Fieliri, (2017), Resident-tourist value co-creation: The role of residents' perceived tourism impacts and life satisfaction, Tourism Management, 61, 436e442

Manuel, Pinto, Silva, \& Woosnan, (2017) Residents' attitudes and the adoption of pro-tourism behaviours: The case of developing island countries, Tourism Management, 61, 523e537

Perez, E. A., \& Nadal, J. R. (2005). Host community perceptions a cluster analysis. Annals of Tourism Research, 32(4), 925e941.

Prahalad, C. K., \& Ramaswamy, V. (2004). Co-creation experiences: The next practice in value creation. Journal of interactive marketing, 18(3), 5e14.

Prebensen, N. K., Woo, E., Chen, J. S., \& Uysal, M. (2013). Motivation and involvement as antecedents of the perceived value of the destination experience. Journal of Travel Research, 52(2), 253e264.

Ritchie, J. R. B., \& Hudson, S. (2009). Understanding and meeting the challenges of consumer/tourist experience research. International Journal of Tourism Research, 11(2), $111 \mathrm{e} 126$.

Sfandla, C., \& Bjo€rk, P. (2013). Tourism experience network: Co-creation of experi- ences in interactive processes. International Journal of Tourism Research, 15(5), 495e506. 
Sharpley, R. (2014). Host perceptions of tourism: A review of the research. Tourism Management, 42, 37e49.

Stylidis, D., Biran, A., Sit, J., \& Szivas, E. M. (2014). Residents' support for tourism development: The role of residents' place image and perceived tourism impacts. Tourism Management, $45,260 \mathrm{e} 274$.

Vargo, S. L., \& Lusch, R. F. (2004). Evolving to a new dominant logic for marketing. Journal of Marketing, 68(1), 1e17.

Woo, E., Kim, H., \& Uysal, M. (2015). Life satisfaction and support for tourism development. Annals of Tourism Research, 50, 84e97.

Yamin,S. 2009. Structural Equation Modeling: Belajar Lebih Mudah Teknik Analisis Data Kuesioner dengan LISREL-PLS, Buku Seri Kedua. Salemba Infotek. Jakarta

Zeithaml, V. A. (1988). Consumer perceptions of price, quality, and value: A means- end model and synthesis of evidence. Journal of Marketing, 52(3), 2e22 